\title{
Defining Concepts of Student Engagement and Factors Contributing to Their Engagement in Schools
}

\author{
Manisah Mohd Ali' ${ }^{1}$, Noorfaziha Hassan² \\ ${ }^{1}$ Faculty of Education, Universiti Kebangsaan Malaysia, Bangi, Malaysia \\ ${ }^{2}$ Sekolah Menengah Saujana, Setiu, Malaysia \\ Email: mma@ukm.edu.my, kay_skywalker@yahoo.com
}

How to cite this paper: Ali, M. M., \& Hassan, N. (2018). Defining Concepts of Student Engagement and Factors Contributing to Their Engagement in Schools. Creative Education, 9, 2161-2170. https://doi.org/10.4236/ce.2018.914157

Received: August 16, 2018

Accepted: October 26, 2018

Published: October 29, 2018

Copyright (c) 2018 by authors and Scientific Research Publishing Inc. This work is licensed under the Creative Commons Attribution International License (CC BY 4.0).

http://creativecommons.org/licenses/by/4.0/

\section{(c) (i) Open Access}

\begin{abstract}
Student engagement has been widely studied and has been linked to success in academic achievement. This paper focuses on contextualizing student engagement in classroom by discussing the different definition based on previous related studies on student engagement. It will answer questions on the different definitions on student engagement have been developed in previous studies and what are the factors contributing to students' engagement in classrooms. It is found that good engagement is defined by the quality of engagement shown in relation to the kind and context of attachment. Three factors related to a good engagement were identified which are family factor, school factor and peer factor. This paper implies on the need for support from different parties for positive student engagement in schools.
\end{abstract}

\section{Keywords}

Student Engagement, Peers, School, Teacher Support, Family

\section{Introduction}

The interest on student engagement has long been explored when in the early 1920 's by John Dewey, an education figure who began studying the question of why students were bored and did not engage with school. Reference (Dewey, 1956) believes that schools play an important role in providing the best educational services to meet the needs of all students. Later, Dewey (1956) suggests that teachers play an important role in promoting positive relationships with students by understanding the students' background and building a learning environment that focuses on relevant and meaningful learning experiences to en- 
hance student involvement in their learning process.

Reference (Bandura, 1977) adds, teachers need to understand student's attitudes and beliefs which affect their involvement and achievement in classroom. Reference (Bandura, 1977) highlights the Social Learning Theory that emphasizes on three interrelated components in understanding student's engagement in classroom. The components are: individual component (self-esteem, trust and attitude), behavior component (achievement or response to the situation) and environment component (peers feedback, parents and teachers). Similarly, Leonard (2008) reinforces that self-esteem, achievement and feedback from others will affect the involvement of students.

Student engagement is one of the indicators of their academic achievement in school. Students actively engaged in school are said to have high academic achievement (Leonard, 2008; Fredricks, Blumenfeld, \& Paris, 2004; Sahil, 2010; Smith, Ito, Gruenewald, \& Yeh, 2010; Sirin \& Rogers-Sirin, 2005) and demonstrate positive attitudes and behaviors (Smith, Ito, Gruenewald, \& Yeh, 2010; Fletcher, 2007; Sirin \& Rogers-Sirin, 2005; Smith et al., 2010). Reference (Salleh, Desa, \& Tuit, 2013) states that student engagement occurs when students are forced to face various obstacles in the task or activity they are participating but they are showing great interest and are happy to do the job. Reference (Leonard, 2008) also sees the involvement of students as one of the major components that contributes to the success of students in school. In addition, engagement is one of the factors that can prevent students from displaying negative behaviors (Morse, Christenson, \& Lehr, 2004).

Studies on student engagement have increased over the last two decades. Student engagement involves the participation of students in school activities, student recognition with school and student appreciation of the school (Finn \& Rock, 1997)). Students who demonstrate active involvement in school are said to have high academic achievement (Leonard, 2008; Fredricks, Blumenfeld, \& Paris, 2004; Smith, Ito, Gruenewald, \& Yeh, 2010; Sirin \& Rogers-Sirin, 2005; Appleton, Christenson, \& Furlong, 2008) and has positive attitudes (Smith, Ito, Gruenewald, \& Yeh, 2010; Fletcher, 2007; Morse, Christenson, \& Lehr, 2004) while, disengaged students usually face the opposite situation as demonstrating low academic achievement and showing negative attitudes and behaviors.

This paper focuses on contextualizing student engagement in classroom by discussing the different definition based on previous related studies on student engagement. It then discusses on the factors that contribute to students' engagement in classroom. Thus, this paper will answer the following questions:

1) What different definitions on student engagement have been developed by researchers?

2) What are the factors contributing to students' engagement in classrooms?

\section{Definitions of Engagement}

Engagement can be seen in various terms such as student participation, academic participation, student involvement, academic involvement, involvement 
in school assignments and involvement. The following table (Table 1) illustrates previous studies' definitions of engagement.

There are common themes found in the three categories of engagement in Table 1. Firstly, a good engagement is defined by its' quality of engagement shown by the students in relation to kind and the context of attachment. Students' engagement studies typically focus on measurable aspects such as behavioral aspects, assignments, attendance to school and disciplinary action applied to them (Azman, Ali, Tamuri, \& Jelas, 2005). Similarly, Bardin \& Lewis (2008) stress that the extent of student engagement is indicated by students' participation in their classes, their enthusiasm in learning and the quality of their completed class assignments.

According to Trowler (2010), engagement involves various variables. The use of only one variable in studying student engagement is irrelevant because it is said to be non-exhaustive. This is because engagement is not merely physical engaged but instead needs to see engagement in terms of emotion and cognition.

Table 1. Empirical based definitions of engagement.

\begin{tabular}{|c|c|c|}
\hline Term & Source & Definition \\
\hline \multirow[t]{5}{*}{ Engagement } & $\begin{array}{c}\text { Audas \& } \\
\text { Willms (2001) }\end{array}$ & The participation of students in the activities held at the school \\
\hline & $\begin{array}{l}\mathrm{Hu} \& \mathrm{Kuh} \\
\quad(2002)\end{array}$ & $\begin{array}{l}\text { The level of participation of students in academic and non-academic } \\
\text { activities and students' appreciation of schooling goals. }\end{array}$ \\
\hline & $\begin{array}{l}\text { Skinner et al. } \\
\text { (2009) }\end{array}$ & $\begin{array}{l}\text { The quality of effort shown by students in educational } \\
\text { activities contributes to expected outcomes. }\end{array}$ \\
\hline & $\begin{array}{l}\text { Suh \& Suh } \\
\quad(2006)\end{array}$ & $\begin{array}{l}\text { The quality of contact or participation of students with the efforts } \\
\text { shown in the school which covers social relationships, } \\
\text { activities, goals' value and the environment. }\end{array}$ \\
\hline & $\begin{array}{l}\text { Furlong } \\
\text { et al. (2003) }\end{array}$ & $\begin{array}{l}\text { Denotes relationship, participation, attachment and } \\
\text { integration within the environment or task. }\end{array}$ \\
\hline \multirow[t]{4}{*}{$\begin{array}{c}\text { School } \\
\text { Engagement }\end{array}$} & $\begin{array}{l}\text { Fredricks } \\
\text { et al. (2004) }\end{array}$ & $\begin{array}{l}\text { Emotional engagement (positive and negative reactions } \\
\text { to teachers, peers, academics and schools). }\end{array}$ \\
\hline & $\begin{array}{c}\text { Klem \& } \\
\text { Connell }(2004)\end{array}$ & $\begin{array}{l}\text { Affective, behavioral and cognitive engagement among students } \\
\text { with peer groups, in the classroom and at school. }\end{array}$ \\
\hline & $\begin{array}{l}\text { Jimerson et al. } \\
\qquad(2003)\end{array}$ & $\begin{array}{l}\text { Continuous engagement (including behavioral, emotional } \\
\text { and cognitive components) and responses to challenges. }\end{array}$ \\
\hline & $\begin{array}{l}\text { Chapman } \\
(2003)\end{array}$ & $\begin{array}{l}\text { Types of affective engagement } \\
\text { (feelings about school, teacher and peers), behaviors } \\
\text { (observable actions) and cognitive (perceptions and beliefs). }\end{array}$ \\
\hline \multirow[t]{5}{*}{$\begin{array}{l}\text { Students } \\
\text { Engagement }\end{array}$} & Marks (2000) & $\begin{array}{l}\text { Cognitive, behavioral and affective desires to participate } \\
\text { in specific tasks in the daily activities of the school. }\end{array}$ \\
\hline & $\begin{array}{l}\text { Salleh et al. } \\
\text { (2013) }\end{array}$ & $\begin{array}{l}\text { Desire, need, the will of the students to engage in routine } \\
\text { school activities such as attending classes, assigning teachers' } \\
\text { assignments and following teachers' instruction in the classroom. }\end{array}$ \\
\hline & $\begin{array}{l}\text { Leonard } \\
(2008)\end{array}$ & $\begin{array}{l}\text { Presenting oneself to school, participating in organized activities in } \\
\text { tandem with the persistent effort and feeling of "sense of belonging". }\end{array}$ \\
\hline & $\begin{array}{l}\text { Yazzie-Mintz } \\
\quad(2010)\end{array}$ & $\begin{array}{l}\text { The student psychological process includes attention, } \\
\text { interest, application and effort in learning. }\end{array}$ \\
\hline & $\begin{array}{l}\text { Azman et al. } \\
\qquad(2005)\end{array}$ & $\begin{array}{l}\text { Cognitive/intellectual/academic, social/behavior/participation } \\
\text { and emotion (relationship between feeling with school includes } \\
\text { achievement, school climate, relationship with teachers and peers). }\end{array}$ \\
\hline
\end{tabular}


Reference (Ali \& Hassan, 2014), introduces three dimensions of student engagement where each dimension of engagement can be positive or negative depending on the form of student engagement. Both types of engagement are the engagement of active learners especially in learning, but are demonstrated in two different situations, positive engagement (as expected by teachers) and negative engagement (unexpected to be shown by the students). Among these two contrastive engagement, there are also groups of students who are not directly engaged or in other words are withdrawing in an activity primarily related to academic learning. This means that a student may show behavioral, emotional and cognitive involvement either by positive engagement, negative engagement or indirect engagement. Reference (Ali \& Hassan, 2014) has made comparison of dimension of engagement by providing examples as in Table 2.

To increase positive engagement, teachers play an important role in changing academic and social barriers by creating opportunities to increase student engagement through effective planned teaching and learning strategies (Sinclair, Christenson, Lehr, \& Anderson, 2003). Therefore, teacher support is important in influencing students' engagement in academics which in turn contributes to the success of students in school.

As for the students themselves, their engagement is impacted by the socio-emotion context that they are in. A strong and positive belief of oneself in handling relationship contributes to the strength of their engagement. In the next section, this paper explores the factors that contribute to students' engagement in schools.

\section{Factors Contributing to Students' Engagement in Schools}

Reference (Audas \& Willms, 2001) lists contextual factors such as school, home and peer factors as contributing factors for student engagement. Earlier, (Hamid, Othman, Ahmad, \& Ismail, 2011) state that the three contexts in the student microsystem (according to the Ecological Theory by Bronfenbrenner) are families, schools and peers should be noted when studying the involvement of students at school. While (Sahil, 2010) states that contextual factors affecting student involvement are family, peers, school environment and neighborhood. Based on the findings of these studies, it can be concluded that contextual

Table 2. Dimensions of student engagement.

\begin{tabular}{lccc}
\hline & $\begin{array}{c}\text { Positive } \\
\text { Engagement }\end{array}$ & $\begin{array}{c}\text { Indirect } \\
\text { Engagement }\end{array}$ & $\begin{array}{c}\text { Negative } \\
\text { Engagement }\end{array}$ \\
Behavior & $\begin{array}{c}\text { Attend classes, } \\
\text { participate in activities. }\end{array}$ & $\begin{array}{c}\text { Skip classes } \\
\text { with reasons. }\end{array}$ & $\begin{array}{c}\text { Disrupt and } \\
\text { distract classes. }\end{array}$ \\
Cognition & Interest. & Bored \\
the task requirements. & Late submission of assignments & Disapproved \\
\hline
\end{tabular}

(Source: Ali \& Hassan, 2014). 
factors such as family factors, school factors and peer factors are among the main factors contributing to the engagement of students in schools.

\subsection{Family Factors}

Families are the main institutions in a society as they play a great role in creating a harmonious society (Marchant, Paulson, \& Rothlisberg, 2001). Family support and involvement can range from the provision of learning environment, setting high expectations of education, providing motivational support and playing a fundamental role by controlling and monitoring the development of children. In a family institution, parents are the most influential individuals to children. The care, education, affection and attention from parents influence the development of their children (Marchant, Paulson, \& Rothlisberg, 2001). However, each family is unique and different. This is because children who come from different background go through different growth experiences according to their respective families.

Studies from (McInerney, 2010) found that parents were a factor in encouraging children to experiment. Parents who focus on the children's needs and ambitions as well as encouraging and supporting them, promote for their children to be more successful in their education. According to Knollmann \& Wild (2007), parental involvement in children's education is largely related to the children's engagement in the development of their education. Reference (McInerney, 2010) also lists three reasons why parents are involved in the development of their children's education. Firstly, parents believe their role in the development of children's education. Secondly, parents believe that they can help children to be successful in school, and lastly, opportunities and insistence provided by the school.

Apart from being responsible for raising children, parents can also influence the academic progress of their children in school. Reference (Inman, 2008) argue that parents can help to improve their child's learning ability by showing interest in their child's academic tasks and monitoring them to complete their school's assignment at home. In addition, parental support can help motivate and further enables students to be cognitively, behaviorally and emotional engaged (Sahil, 2010). As noted by Yazzie-Mintz (2010), parental involvement with their child's schooling affects the engagement of their children at primary and secondary levels.

\subsection{School Factor}

Context of the school environment is a critical factor that contributes to student engagement. Context refers to the occurrence of an event and the context of the environment of each school is different. The school environment has had a strong influence on student participation and creating a "sense of belonging" in the students towards the school. The findings of (Smith, Ito, Gruenewald, \& Yeh, 2010) shows that school factors such as trustworthiness, sense of belonging, justice, consistency, encouraging factors and attractive environment have high cor- 
relation with student satisfaction. A positive school environment is an environment that helps students learn by providing a fair environment, mutual respect, security and encouraging positive communication (Yazzie-Mintz, 2010). In addition, the classroom environment that supports student engagement is when the student gets high help and expectations from teachers and peers during the learning process.

According to (Bardin \& Lewis, 2011), the context of the school environment is represented by the "4Cs" concept namely, culture, community, curriculum and co-curriculum. The $4 \mathrm{Cs}$ concept as introduced by (Bardin \& Lewis, 2011) is described in Table 3.

In line with the 4Cs concept introduced by (Bardin \& Lewis, 2011), it is found that teachers are school communities that contribute to the involvement of students in school. According to Sahil (2010), one of the main factors affecting student perceptions in their academic environment is teachers. Most studies have found that support and encouragement from teachers are also important for students to actively engage themselves (Smith, Ito, Gruenewald, \& Yeh, 2010; Trowler, 2010; Li, Doyle Lynch, Kalvin, Liu, \& Lerner, 2011). This later becomes a mark for academic achievement, self-directed learning strategies and disruptive behaviors shown by the students (Sahil, 2010).

\subsection{Peer Factor}

There are researchers who have begun to see the potential relationship between academic behaviors such as school engagement, peer-to-peer relationships by stating that peers are significant people and play an important role in the development of psychosocial and education of an adolescent (Poulin \& Chan, 2010). Adolescent share with their peers similar characteristics of teenagers like autonomy, desire and peer orientation. This sharing indicates that peer relationships are very important in the life of adolescents.

The stability and quality of peer relationships, however, will change over time (Way \& Greene, 2006). Reference (Way \& Greene, 2006) stress that changes in relationships with peers are not only due to changes of schools but also due to

Table 3. The 4Cs concept.

\begin{tabular}{cl}
\hline \multicolumn{1}{c}{ Concept } & \multicolumn{1}{c}{ Statement } \\
\hline School Culture & $\begin{array}{l}\text { School's Mission and vision, trust, value, tradition, aspiration, } \\
\text { school structure and organization and curriculum matters. }\end{array}$ \\
A relationship that reflects the school and its members, \\
the interaction between students, teachers and administrators \\
with communities and individuals outside the school. \\
The relationships built should be of great quality and depth.
\end{tabular}


the instability of the social relationship that naturally occurred in adolescents. Most studies consider that the relationship between school engagements with peer relationships will always change over time (Poulin \& Chan, 2010). Peer-to-peer relationships are rapidly evolving and undergoing changes. This may cause some aspects of peer relationships to be less important while other aspects will be more prominent and influence students across time.

\section{Conclusion}

Student engagement is one of the important factors that should be emphasized in education. The engagement of students is often associated with academic achievement and it can be a tool in addressing disciplinary problems in schools. In order to promote and improve the level of engagement among students, collaboration between school administrators, teachers and parents is necessary in planning relevant activities that not only emphasizes on academic achievement but also building the socio-emotional development of students, and understanding the right definitions of engagement in the school environment.

Previous studies discussed in this paper suggest that the engagement of active students in school brings positive results in the emotional, behavioral and cognitive development of these students. This contributes to high academic achievement.

Teachers are instrumental in changing barriers in academia and social by creating opportunities to increase student engagement through planned strategies by applying effective learning theory. Therefore, teacher support is important in influencing the engagement of students in academics which in turn contributes to the success of students in school. Acceptance and rejection of peers also influence the engagement of students as peers will encourage the development of student social relationships, build a sense of comfort, and inspire them to be active in school. This paper suggests that studies can be conducted in exploring students' engagement and significant contributing factors of such engagement.

\section{Conflicts of Interest}

The authors declare no conflicts of interest regarding the publication of this paper.

\section{References}

Ali, M. M., \& Hassan, N. (2014). Perspektif guru terhadap keterlibatan akademik dalam kalangan murid dengan ketidakupayaan penglihatan. Jurnal Pendidikan Malaysia, 39, 109-114

Appleton, J. J., Christenson, S. L., \& Furlong, M. J. (2008). Student Engagement with School: Critical Conceptual and Methodological Issues of the Construct. Psychology in the Schools, 45, 369-386. https://doi.org/10.1002/pits.20303

Audas, R., \& Willms, J. D. (2001). Engagement and Dropping out of School: A Life Course Perspective: Human Resources and Social Development Canada. 
http://www.esdc.gc.ca/cgi-bin/op-so/err/404-fra.asp?servertype=apache\&p=404;http:// www.esdc.gc.ca/en/cs/sp/hrsd/pre/publications/research/2001-000175/sp-483-01-02E.p df

Azman, N., Ali, M. M., Tamuri, A., \& Jelas, A. M. (2005). Effective Higher Educational Practices: A Survey of Student Engagement. Malaysian Journal of Learning and Instruction, 2, 95-119.

Bandura, A. (1977). Self-Efficacy: The Exercise of Control. New York: Freeman.

Bardin, J. A., \& Lewis, S. (2008). A Survey of the Academic Engagement of Students with Visual Impairments in General Education Classes. Journal of Visual Impairment \& Blindness, 102, 472-483.

Bardin, J. A., \& Lewis, S. (2011). General Education Teachers' Ratings of the Academic Engagement Level of Students Who Read Braille: A Comparison with Sighted Peers. Journal of Visual Impairment \& Blindness, 105, 479-492.

Chapman, E. (2003). Alternative Approaches to Assessing Student Engagement Rates. Practical Assessment, 8, 1-7.

Dewey, J. (1956). The Child and the Curriculumum and the School and Society. Chicago, IL: University of Chicago Press.

Finn, J. D., \& Rock, D. A. (1997). Academic Success among Students at Risk for School Failure. Journal of Applied Psychology, 82, 221.

https://doi.org/10.1037/0021-9010.82.2.221

Fletcher, A. (2007). Defining Student Engagement: A Literature Review. https://soundout.org/defining-student-engagement-a-literature-review/

Fredricks, J. A., Blumenfeld, P. C., \& Paris, A. H. (2004). School Engagement: Potential of the Concept, State of the Evidence. Review of Educational Research, 74, 59-109. https://doi.org/10.3102/00346543074001059

Furlong, M. J., Whipple, A. D., Jean, G. S., Simental, J., Soliz, A., \& Punthuna, S. (2003). Multiple Contexts of School Engagement: Moving toward a Unifying Framework for Educational Research and Practice. The California School Psychologist, 8, 99-113. https://doi.org/10.1007/BF03340899

Hamid, Z. A., Othman, J., Ahmad, A., \& Ismail, I. A. (2011). Hubungan antara penglibatan ibubapa dan pencapaian akademik pelajar miskin di negeri Selangor. Journal of Islamic and Arabic Education, 3, 31-40.

Hu, S., \& Kuh, G. D. (2002). Being (Dis) Engaged in Educationally Purposeful Activities: The Influences of Student and Institutional Characteristics. Research in Higher Education, 43, 555-575. https://doi.org/10.1023/A:1020114231387

Inman, S. F. (2008). Exploring the Relationship between Student Engagement Factors and Entry to Postsecondary Programs: A Secondary Analysis. Doctoral Dissertation, University of Oregon. http://ejournal.ukm.my/jpend/article/view/12047

Jimerson, S. R., Campos, E., \& Greif, J. L. (2003). Toward an Understanding of Definitions and Measures of School Engagement and Related Terms. The California School Psychologist, 8, 7-27. https://doi.org/10.1007/BF03340893

Klem, A. M., \& Connell, J. P. (2004). Relationships Matter: Linking Teacher Support to Student Engagement and Achievement. Journal of School Health, 74, 262-273. https://doi.org/10.1111/j.1746-1561.2004.tb08283.x

Knollmann, M., \& Wild, E. (2007). Quality of Parental Support and Students' Emotions during Homework: Moderating Effects of Students' Motivational Orientations. European Journal of Psychology of Education, 22, 63.

Leonard, S. H. (2008). Measuring Cognitive and Psychological Engagement in Middle 
School Students. The University of South Dakota: D. Ed. Thesis. http://search.proquest.com.www.ezplib.ukm.my/docview/304464018/fulltextPDF/1377 DCE32E07B5D9A43/1? accountid=41453

Li, Y., Doyle Lynch, A., Kalvin, C., Liu, J., \& Lerner, R. M. (2011). Peer Relationships as a Context for the Development of School Engagement during Early Adolescence. International Journal of Behavioral Development, 35, 329-342.

Marchant, G. J., Paulson, S. E., \& Rothlisberg, B. A. (2001). Relations of Middle School Students' Perceptions of Family and School Contexts with Academic Achievement. Psychology in the Schools, 38, 505-519. https://doi.org/10.1002/pits.1039

Marks, H. M. (2000). Student Engagement in Instructional Activity: Patterns in the Elementary, Middle, and High School Years. American Educational Research Journal, 37, 153-184. https://doi.org/10.3102/00028312037001153

McInerney, D. M. (2010). The Role of Sociocultural Factors in Shaping Student Engagement in Hong Kong: An Ethnic Minority Perspective. Hong Kong: The Hong Kong Institute of Education.

Morse, A. B., Christenson, S. L., \& Lehr, C. A. (2004). School Complementation and Student Engagement: Information and Strategies for Parents. In A. S. Canter, L. Z. Paige, M. D. Roth, I. Romero, \& S. A. Carroll (Eds.), Helping Children at Home and at School II: Handouts for Families and Educators (pp. S2-69-S2-71). Bethesda, MD: National Association of School Psychologists.

Poulin, F., \& Chan, A. (2010). Stability and Changes in Children and Adolescents Friendships. Developmental Review, 30, 257-272. https://doi.org/10.1016/j.dr.2009.01.001

Sahil, S. A. S. (2010). A Structural Model of the Relationships between Teacher, Peer and Parental Support, Behavioural Engagement, Academic Efficacy and Cognitive Engagement of Secondary School Adolescents. Sintok: Universiti Utara Malaysia.

Salleh, A. M., Desa, M. M., \& Tuit, R. M. (2013). The Relationship between the Learning Ecology System and Students' Engagement: A Case Study in Selangor. Asian Social Science, 9, 110-117. https://doi.org/10.5539/ass.v9n12p110

Sinclair, M. F., Christenson, S. L., Lehr, C. A., \& Anderson, A. R. (2003). Facilitating Student Engagement: Lessons Learned from Check \& Connect Longitudinal Studies. The California School Psychologist, 8, 29-41. https://doi.org/10.1007/BF03340894

Sirin, S. R., \& Rogers-Sirin, L. (2005). Components of School Engagement among African American Adolescents. Applied Developmental Science, 9, 5-13. https://doi.org/10.1207/s1532480xads0901_2

Skinner, E. A., Kindermann, T. A., \& Furrer, C. J. (2009). A Motivational Perspective on Engagement and Disaffection: Conceptualization and Assessment of Children's Behavioral and Emotional Participation in Academic Activities in the Classroom. Educational and Psychological Measurement, 69, 493-525.

https://doi.org/10.1177/0013164408323233

Smith, D. C., Ito, A., Gruenewald, J., \& Yeh, H. L. (2010). Promoting School Engagement: Attitudes toward School among American and Japanese Youth. Journal of School Violence, 9, 392-406. https://doi.org/10.1080/15388220.2010.509308

Suh, S., \& Suh, J. (2006). Educational Engagement and Degree Attainment among High School Dropouts. Educational Research Quarterly, 29, 11-20.

Trowler, V. (2010). Students Engagement Literature Review. The Higher Education Academy.

Way, N., \& Greene, M. L. (2006). Trajectories of Perceived Friendship Quality during 
Adolescence: The Patterns and Contextual Predictors. Journal of Research on Adolescence, 16, 293-320. https://doi.org/10.1111/j.1532-7795.2006.00133.x

Yazzie-Mintz, E. (2010). Charting the Path from Engagement to Achievement: A Report on the 2009 High School Survey of Student Engagement. Bloomington, IN: Center for Evaluation \& Education Policy. 